\title{
PRESKÚMAVANIE ROZHODNUTÍ TELEKOMUNIKAČNÉHO ÚRADU SR PODLA ZÁKONA Č. 610/2003 Z.Z. O ELEKTRONICKÝCH KOMUNIKÁCIÁCH V PLATNOM ZNENÍ
}

\author{
Branislav Olšák ${ }^{*}$
}

Úvod

V rámci predmetu činnosti Telekomunikačný úrad Slovenskej republiky (d'alej len „TÚ SR“) ako orgán štátnej správy voblasti elektronických komunikácií vydáva rozhodnutia, ktoré zverejňuje vo Vestníku TÚ SR a informatívne na internete. Okrem informatívnej funkcie tak prispieva k verejnej kontrole občanmi.

Rozhodnutím TÚ SR sa upravujú konkrétne právne pomery fyzických a právnických osôb (účastníci konania) v oblasti elektronických komunikácií. Účastník konania môže podat' proti rozhodnutiam TÚ SR opravný prostriedok. Základnou úlohou inštitútu opravných prostriedkov je preskúmanie a prípadná náprava nesprávnych a nezákonných rozhodnutí.

Na postup podl'a zákona č. 610/2003 Z.z. o elektronických komunikáciách v znení neskorších predpisov (d’alej len „zákon“) sa aplikujú ustanovenia zákona č. 71/1967 Zb. o správnom konaní v znení neskorších predpisov (d’alej len „správny poriadok“). V ustanovení $\S 72$ ods. 1 zákona sa výslovne uvádza: „na konanie podla tohto zákona sa vztahuje všeobecný predpis o sprá vnom konaní, ak tento zákon neustanovuje inak“. [1]

Aplikácia správneho poriadku má podpornú (subsidiárnu) povahu. Preto komplexnú právnu úpravu opravných prostriedkov proti rozhodnutiam TÚ SR poskytne iba kombinácia ustanovení $§ 72$ ods. 3 a 4 zákona a ustanovení $§ 53$ a násl. správneho poriadku (primerane).

Preskúmat' možno neprávoplatné alebo výnimočne aj právoplatné rozhodnutia TÚ SR. Z uvedeného vyplýva aj zákonné členenie opravných prostriedkov:

- riadne opravné prostriedky

- mimoriadne opravné prostriedky.

\section{Riadne opravné prostriedky}

Riadne opravné prostriedky smerujú proti rozhodnutiam TÚ SR, ktoré nenadobudli právoplatnost. Právna veda rozlišuje procesnú stránku právoplatnosti a materiálnu stránku právoplatnosti.

Procesná stránka právoplatnosti je upravená v $§ 52$ ods. 1 správneho poriadku. Podl'a citovaného ustanovenia rozhodnutie TÚ SR nadobúda právoplatnost', ak je rozhodnutie doručené, a to $\mathrm{v}$ súlade $\mathrm{s}$ príslušnými ustanoveniami správneho poriadku (pozri § 24 a násl.) a zároveň nie je možné ho napadnút' riadnym opravným prostriedkom.

Materiálna stránka právoplatnosti sa vzt’ahuje na obsah rozhodnutia a znamená nezrušitel'nost' a nezmenitel'nost' aktu. Existencia materiálnej právoplatnosti v zásade vylučuje prejednanie tej istej veci znova (prekážka res iudicata). Z toho vyplýva, že

\footnotetext{
* JUDr. Branislav Olšák,

e-mail: brunislaw_olsak@yahoo.com
} 
materiálna stránka právoplatnosti zabraňuje, aby sa vo veci znova konalo a rozhodovalo, s výnimkou prípadov podl'a/za podmienok ustanovených zákonom - mimoriadne opravné prostriedky.[6] Platná právna úprava elektronických komunikácií pozná jediný druh riadneho opravného prostriedku a to rozklad.

\subsection{Rozklad}

Rozklad je špecifický opravný prostriedok proti prvostupňovým rozhodnutiam ústredných orgánov štátnej správy. Pre uplatnenie rozkladu platia tieto podmienky:

- rozklad môže podat' len účastník konania,

- rozklad musí byt' podaný v ustanovenej lehote a

- rozklad treba podat' na určenom mieste, pričom musí byt' prípustný. [4]

Konanie o rozklade sa začína výlučne na návrh účastníka konania (tzv. dispozičná zásada). Rozklad treba podat' do 15 dní odo dňa oznámenia rozhodnutia na tom odbore TÚ SR, ktorý napadnuté rozhodnutie vydal.

Na konanie o rozklade sa primerane vzt'ahujú ustanovenia správneho poriadku o odvolacom konaní. Rozklad nemá devolutívny účinok, t.j. oprávnenie rozhodnút' o rozklade neprechádza na vyšší orgán. Ked’že už niet vyššieho, inštančne nadriadeného orgánu, takýto účinok ani nie je možný. Rozklad má však odkladný (suspenzívny) účinok, to znamená, že právne účinky rozhodnutia, až do vybavenia rozkladu nenastanú. Vznik právoplatnosti sa posúva do vybavenia rozkladu a napadnuté rozhodnutie nemožno zatial' vykonat', okrem osobitných prípadov (naliehavý všeobecný záujem a vznik nenahraditel'nej ujmy) resp. v prípadoch ustanovených osobitným právnym predpisom. Napadnuté rozhodnutie sa preskúmava v celom rozsahu.[3] Z toho vyplýva, že TÚ SR nie je viazaný návrhom účastníka konania, preto môže vyzniet' aj v neprospech účastníka (reformatio in peius); môže však vyzniet' aj na prospech účastníka.

O rozklade rozhoduje vždy vedúci ústredného orgánu štátnej správy. V prípade TÚ SR ako príslušný správny orgán ( $\$ 5$ správneho poriadku) rozhoduje jeho predseda, a to na základe návrhu ním zriadenej osobitnej rozkladovej komisie. Správny poriadok neobsahuje užšiu úpravu o zložení rozkladovej komisie, ani o jej postupe v konaní. Z hl'adiska nestrannosti sa vyžaduje, aby členmi tejto rozkladovej komisie neboli len pracovníci TÚ SR. Treba však podotknút', že rozkladová komisia je poradným orgánom predsedu TÚ SR, preto nie je názorom tejto komisie viazaný.[3]

Rozhodnutie o rozklade je konečné a proti tomuto rozhodnutiu nemožno podat' rozklad. Takéto rozhodnutie môže byt' preskúmané na základe podania mimoriadneho opravného prostriedku (obnova konania alebo preskúmanie rozhodnutia mimo odvolacieho konania).

Taktiež účastník konania môže požiadat' o preskúmanie rozhodnutia súd, v rámci tzv. správneho súdnictva. Pôjde o žalobu o preskúmanie zákonnosti rozhodnutia TÚ SR podl'a $\S$ 244 a násl. Občiansko-súdneho poriadku (O.s.p.). Žalobu možno podat' na Najvyšší súd SR v zákonnej dvojmesačnej lehote.

R 32/1996: Sprá vny orgán rozhodujúci v poslednom stupni, nie je povinný poučovat' účastníkov konania o možnosti domáhat'sa preskúmania jeho rozhodnutia súdom podl'a piatej časti O.s.p. 


\section{Mimoriadne opravné prostriedky}

Proti už právoplatným rozhodnutiam TÚ SR možno uplatnit' mimoriadne opravné prostriedky, ktorými sú:

- obnova konania a

- preskúmanie rozhodnutia mimo odvolacieho konania.

Rozdielnost' týchto inštitútov spočíva $\mathrm{v}$ tom, že účastník konania má na obnovu konania právny nárok, na rozdiel od inštitútu preskúmania rozhodnutia mimo odvolacieho konania, podl'a ktorého účastník konania nemá na preskúmanie rozhodnutia právny nárok. Ďalší rozdiel je v tom, že obnova konania je určená predovšetkým k náprave skutkových omylov (inak vnímaná skutočnost' dôležitá pre posúdenie veci), ktoré boli podkladom pre vydanie napadnutého rozhodnutia TÚ SR, kým preskúmavaním rozhodnutia mimo odvolacieho konania sa sleduje v podstate náprava právnych omylov.

\subsection{Obnova konania}

Zákonné predpoklady na povolenie obnovy konania sú:

- právoplatné rozhodnutie TÚ SR, proti ktorému účastník konania podal návrh na obnovu konania alebo nariadenie obnovy konania TÚ SR (ex offo),

- existencia niektorého $\mathrm{z}$ dôvodov obnovy konania, ktoré taxatívne určujú ustanovenia $\S 62$ ods. 1 písm. a) až e) správneho poriadku a

- zachovanie ustanovenej lehoty.[4]

Účastník je oprávnený podat' návrh na obnovu konania v lehote 3 mesiacov odo dňa, kedy sa dozvedel o dôvodoch obnovy konania (tzv. subjektívna lehota), najneskôr do 3 rokov od právoplatnosti rozhodnutia (tzv. objektívna lehota). V rovnakej lehote môže preskúmanie rozhodnutia nariadit' aj TÚ SR. Príklad: Rozhodnutie TÚ SR nadobudlo právoplatnost' dňa 30. júna 2004. Účastník konania sa preukázatel’ne dozvedel o dôvodoch obnovy konania 15. júna 2007. Žiadost'o obnovu konania podal na TÚ SR dña 10. júla 2007. Účastník dodržal subjektívnu trojmesačnú lehotu, t,j. žiadost' bola podaná do troch mesiacov odo dña, ked'sa preukázatel’ne dozvedel o dôvodoch obnovy, avšak nebola dodržaná objektívna trojročná lehota. Nakolko žiadost' nebola podaná najneskôr do troch rokov odo dňa právoplatnosti rozhodnutia, ktorého sa obnova konania týka, obnovu konania nie je možné povolit'.

Návrh na obnovu konania sa podáva voči prvostupňovým rozhodnutiam TÚ SR na príslušný odbor TÚ SR, ktorý rozhodnutie vydal a voči druhostupňovým rozhodnutiam TÚ SR, t.j. rozhodnutiam o rozklade predsedovi TÚ SR.

Podl'a zákona č. 145/1995 Z.z. v znení neskorších predpisov je fyzická osoba povinná zaplatit' pri podaní návrhu na obnovu konania a preskúmania rozhodnutia mimo odvolacieho konania správny poplatok vo výške 500,-Sk. Právnická osoba a fyzická osoba, ktorá je oprávnená na podnikanie je povinná zaplatit' správny poplatok vo výške 5000,-Sk. Poplatok sa vráti, ak sa obnova konania povolí alebo ak sa podnetu na preskúmanie rozhodnutia mimo odvolacieho konania vyhovelo v plnom rozsahu.

Dôvody na obnovu konania sú nasledovné:

$\checkmark$ rozhodnutie TÚ SR záviselo od posúdenia predbežnej otázky, o ktorej príslušný orgán neskôr rozhodol inak. Uvedená skutočnost' môže byt' dôvodom obnovy konania len vtedy, ak sa odchyl'uje od úsudku, ktorý si o predbežnej otázke urobil TÚ SR a to do tej miery, že rozhodnutie TÚ SR je nesprávne.

$\checkmark$ rozhodnutie TÚ SR sa opiera o dôkazy, ktoré sa ukázali byt' nepravdivé (najmä falšované listiny a iné falošné doklady...). 
$\checkmark$ rozhodnutie TÚ SR sa dosiahlo činom, ktorý bol kvalifikovaný ako trestný čin (trestné činy, ktorými sa dosiahlo rozhodnutie, môžu byt' rôzne, najmä falšovanie a pozmeňovanie verejnej listiny, úradnej pečate a úradnej uzávery, prijímanie úplatku a pod.).

$\checkmark$ vyšli najavo nové skutočnosti alebo dôkazy, ktoré sa nemohli v konaní uplatnit' bez zavinenia účastníka konania. Pre nové skutočnosti alebo dôkazy sa konanie obnoví len za predpokladu, že vyšli najavo po právoplatnosti rozhodnutia a že ich účastník konania v pôvodnom konaní bud' vôbec nepoznal, alebo ich bez vlastného zavinenia nemohol uplatnit'. Z uvedeného vyplýva, že ide nové skutočnosti alebo dôkazy, ktoré vyšli najavo po právoplatnosti rozhodnutia, avšak existovali už v čase, ked' sa príslušná vec prejednávala $\mathrm{v}$ pôvodnom konaní, ale účastník konania o nich nevedel alebo bez vlastného zavinenia ich nemohol uplatnit', t.j. do okamihu, než mu márne uplynula lehota na podanie rozkladu resp. ak uplatnil rozklad, do doby, pokial' nebolo o rozklade rozhodnuté. Dôvod pre obnovu konania nie je $\mathrm{v}$ prípade, ak účastník konania poznal okolnosti alebo dôkazy už v čase, ked' prebiehalo pôvodné konanie a z vlastnej viny ich neuplatnil.

$\checkmark$ rozhodnutie vydal TÚ SR ako vylúčený orgán a nápravu nebolo možné dosiahnut' v konaní o rozklade.

$\checkmark$ nesprá vnym postupom TÚ SR sa účastníkovi konania odňala možnost' zúčastnit' sa na konaní a nápravu nebolo možné urobit' v konaní o rozklade.[2]

Konanie pri obnove konania má dve štádiá:

1. konanie o povolení alebo nariadení obnovy konania - tzv. obnovovacie konanie. V tomto štádiu TÚ SR rozhoduje iba o prípustnosti obnovy (splnenie zákonných predpokladov), pričom predmetom preskúmavania nie je meritórny výrok napadnutého rozhodnutia.

2. konanie po povolení obnovy konania - tzv. obnovené konanie, v ktorom TÚ SR vec prejedná a znova rozhodne.

Ak sa zistí, že skutočnosti uvedené v žiadosti nezakladajú ani jeden z vyššie uvedených dôvodov na povolenie obnovy konania, tak TÚ SR žiadost' o obnovu konania zamietne rozhodnutím. V tomto prípade je možné podat' opravný prostriedok - rozklad.

Povolenie obnovy konania má za následok odloženie resp. zastavenie výkonu rozhodnutia (tzv. suspenzívny účinok), pokial' ešte neprišlo $k$ jeho výkonu a zároveň sa pripúšt’a zmena k horšiemu, t.j. v neprospech subjektu, ktorý podal návrh na obnovu konania. Rozhodnutie o povolení alebo nariadení obnovy konania musí obsahovat' aj rozsah obnoveného konania a dôvody, pre ktoré sa konanie obnovuje. [3]

Vydaním nového rozhodnutia vo veci sa súčasne zrušuje pôvodné rozhodnutie TÚ SR. Nakol'ko výsledkom nového konania je nové rozhodnutie vo veci samej, možno proti nemu podat' rozklad. Obnovené konanie uskutoční príslušný odbor TÚ SR alebo predseda TÚ SR, podl'a toho, ktorého sa dôvod obnovy týka; ak sa týka dôvod obnovy konania oboch stupňov, uskutoční konanie príslušný odbor TÚ SR.

\subsection{Preskúmanie rozhodnutia mimo odvolacieho konania}

Preskúmanie rozhodnutia mimo odvolacieho konania sa môže začat’ len z podnetu TÚ SR, pričom predmetom tohto spôsobu preskúmavania je výlučne zákonnost' rozhodnutia (t.j. rozpor so zákonom resp. všeobecne záväzným právnym predpisom). Predpoklady na preskúmanie rozhodnutia mimo odvolacieho konania sú: [4] 
- nezákonné právoplatné rozhodnutie TÚ SR,

- rozhodnutie mimo odvolacieho konania môže preskúmat' iba TÚ SR,

- rozhodnutie mimo odvolacieho konania možno preskúmat' len v ustanovenej lehote.

Ako je vyššie spomenuté, na preskúmanie rozhodnutia mimo odvolacieho konania nemá účastník konania právny nárok, preto podnet na preskúmanie rozhodnutia môže podat' ktokol'vek. Podnetom môže byt' napríklad st'ažnost' či žiadost'. Avšak takáto žiadost' resp. st'ažnost' nemá povahu podania podl'a $§ 19$ správneho poriadku, ktorá by nevyhnutne smerovala k začatiu konania. Na základe predmetného podania TÚ SR iba posudzuje, či existujú predpoklady na začatie vlastného konania o preskúmaní rozhodnutia mimo odvolacieho konania.

$\mathrm{Na}$ preskúmanie rozhodnutia mimo odvolacieho konania je príslušný inštančne nadriadený orgán tomu orgánu, ktorý vydal právoplatné rozhodnutie. Z toho vyplýva, že návrh na preskúmanie rozhodnutia mimo odvolacieho konania je treba podat' voči prvostupňovým rozhodnutiam TÚ SR na príslušný odbor TÚ SR, ktorý rozhodnutie vydal, voči druhostupňovým rozhodnutiam TÚ SR, t.j. rozhodnutiam o rozklade sa podávajú predsedovi TÚ SR. V tomto prípade predseda TÚ SR rozhoduje na základe osobitnej komisie vytvorenej na posudzovanie rozkladov.

Ciel'om preskúmavania je nezákonné (už právoplatné) rozhodnutie TÚ SR zmenit' alebo zrušit', pričom TÚ SR vychádza z právneho stavu a skutkových okolností existujúcich v čase vydania rozhodnutia. Uvedené preskúmavanie je ohraničené 3 ročnou lehotou od právoplatnosti napadnutého rozhodnutia, počas ktorej môže TÚ SR zrušit alebo zmenit' rozhodnutie. Proti novému rozhodnutiu vo veci je prípustný rozklad.

V prípade, že TÚ SR nezistí nezákonnost' preskúmavaného rozhodnutia konanie zastaví podla $\S 30$ správneho poriadku. Aj v tomto prípade je proti rozhodnutiu prípustný rozklad.

\section{Súdne preskúmavanie}

Mimoriadnym spôsobom preskúmania rozhodnutia alebo postupu TÚ SR je preskúmavanie súdom. Táto možnost' sa realizuje podaním žaloby na Najvyšší súd Slovenskej republiky.

Podmienky na uplatnenie súdneho preskúmavania sú:

- návrh na súdne preskúmanie je oprávnený podat' len účastník konania,

- návrh sa musí podat' v zákonom určenej lehote.

Návrh musí smerovat' len proti takému rozhodnutiu TÚ SR, pri ktorom zákon umožňuje súdne preskúmanie. V tomto konaní sa nepojednáva o podstate veci, ale iba o zákonnosti napadnutého rozhodnutia. [5]

\section{Záver}

Reálne uplatnenie ústavného práva na súdnu a inú právnu ochranu uvedené v článku 46 Ústavy SR vyžaduje, aby sa každý mohol procesne bránit’ proti rozhodnutiam, ktoré súdy a iné orgány štátu vydali v prvom stupni, okrem prípadov, ked’ to zákon výslovne vylučuje.

Účelom opravného prostriedku a opravného konania je zákonom predpísaným spôsobom dosiahnut' nápravu právnych alebo skutkových pochybení (alebo oboch skupín týchto pochybení), ktoré vyústili do nezákonného (nespravodlivého) rozhodnutia. [6]

Z uvedeného môžeme konštatovat', že právna úprava opravného konania $\mathrm{v}$ zákone o elektronických komunikáciách sleduje rovnaký zámer - nápravu chybných rozhodnutí TÚ SR. 


\section{Literatúra}

[1] Zákon č. 610/2003 Z.z. o elektronických komunikáciách v znení neskorších predpisov

[2] Zákon č. 71/1967 Zb. o správnom konaní (správny poriadok) v znení neskorších predpisov

[3] Vrabko, M. a kolektív: Správne právo - procesná čast', VO PF UK, Bratislava 2001

[4] Tóthová, K.: Štátna správa, samospráva a občan, VNO PRÁCA, Bratislava 1991

[5] Ševčík, M. a kolektív.: Správne právo procesné, EUROUNION, Bratislava 2005

[6] Mazák, J.: Základy občianskeho procesného práva, IURA EDITION, Bratislava 2004 